\title{
PERCEPTIONS ON THE
}

\section{OBSTACLES OF STRATEGY}

\section{EXECUTION: THE CASE OF}

\author{
Hacettepe University \\ Journal of Economics \\ and Administrative \\ Sciences \\ Vol. 33, Issue 1, 2015 \\ pp. 99-134
}

\section{TURKISH PUBLIC}

\section{ORGANIZATIONS}

\author{
Mustafa KILIÇ \\ Assoc.Prof.Dr., Hacettepe University \\ Faculty of Economics and \\ Administrative Science \\ Department of Business Administration \\ mkilic@hacettepe.edu.tr \\ Ayşe AKTUNA \\ Social Security Institution \\ Asistant Social Security Expert \\ a.aktuna@yahoo.com \\ This article is abstracted from a master thesis \\ by Ayşe SINAN AKTUNA under supervision of \\ Mustafa KILIÇ with the title of "Perception on \\ Factors Affecting Success of Strategy \\ Implementation Process: Turkish Public \\ Organizations Case" at Social Sciences \\ Institute of Hacettepe University.
}

bstract: The main objective of the study
is to determine perceptions of public
employees on strategy execution obstacles in Turkish public organizations. In this context, a questionnaire was applied to the employees of public organizations for examining their perceptions on strategy implementation/ execution process and strategy execution obstacles. These obstacles were classified as in six groups: translation of strategic objectives to employees, motivation level, resistance, development hell, groupthink and underperformance. Findings from the survey suggest that the translation stage was perceived as successful, the level of understanding the strategic objectives and the perceived motivation was high, any other obstacles were not perceived at the public organizations except the development hell obstacle.

Keywords: Strategy, strategic management, strategy implementation, strategy execution, strategy execution obstacles, Turkish public organizations. 


\section{STRATEJİ UYGULAMA}

\begin{tabular}{|c|c|}
\hline ENGELLERİNİN ALGILANMASI: & $\begin{array}{l}\text { Hacettepe Universitesi } \\
\text { iktisadi ve idari Bilimer } \\
\text { Fakültesi Dergisi } \\
\text { Cilt 33, Sayı 1, } 2015\end{array}$ \\
\hline MU KURUMLA & \\
\hline
\end{tabular}
ÖRNEĞİ

\author{
Mustafa KILIÇ \\ Doç.Dr., Hacettepe Üniversitesi \\ İktisadi ve İdari Bilimler Fakültes \\ İşletme Bölümü \\ mkilic@ hacettepe.edu.tr
}

\author{
Ayşe AKTUNA \\ Uzm.Yrd., Sosyal Güvenlik Kurumu \\ a.aktuna@yahoo.com
}

\begin{abstract}
- z: Bu çalışmanın temel amacı Türkiye'de kamu sektöründe stratejilerin başarılı bir şekilde hayata geçirilmesini engelleyen faktörlerin çalışanlar tarafından nasıl algılandığının tespit edilmesidir. $\mathrm{Bu}$ çerçevede, kamu çalışanlarına strateji uygulama süreci ve bu süreçte karşılaşılabilecek engeller konusundaki algılarını ölçmeye yönelik anket uygulanmıştır. Bu engeller stratejik amaçların çalışanlara aktarılması, motivasyon düzeyi, direnç, tıkanma, grup düşüncesi ve düşük performans olmak üzere altı grupta toplanmaktadir. Yapilan analizler sonucunda kamu kurumlarında aktarım aşamasının başarılı olarak algılandığı ortaya çıkmıştır. Bunun göstergelerinden biri olan çalışanların stratejik amaçları anlama ve motivasyon düzeyleri yüksek çıkmıştır. Strateji uygulama engellerinin varlığına yönelik gerçekleştirilen analizler sonucunda ise tıkanma engeli dışındaki engellerin kamu kurumlarında algılanmadığı görülmüştür.
\end{abstract}

Anahtar Sözcükler: Strateji, stratejik yönetim, stratejnin uygulanmasi, stratejnin hayata geçirilmesi, strateji uygulama engelleri, Türk kamu kurumları. 


\section{INTRODUCTION}

Implemeting strategies is vital for both public and private organizations and the most superior strategy will be useless without implementation. The concept of strategy implementation may seem quite straightforward at first but transforming strategies into action is a far more complex and difficult task. (Aaltonen, Ikävalko 2002: 415). Hrebiniak (2006: 12) also notes that "making strategy work is more difficult than strategy making" and "sound plans ... die because of a lack of execution know-how and ability to control organizational and political obstacles that stands in the way of effective implementation".

When literature on strategic management is examined, it is seen that majority of the studies are on strategic planning (Noble, 1999: 119). Although perfect strategies emerged as a result of strategic planning, if a successful implementation process was not experienced, it would not be possible to successfully execute strategy. Therefore, factors influencing success of strategy execution/ implementation process should be identified and actions should be taken for the obstacles that may be encountered during this process.

Efforts to establish legal and intellectual infrastructure for strategic management in Turkey began in the early 2000s. As a result of these efforts, with the Public Financial Management and Control Law (PFMC/Law No. 5018), public administrations and some municipalities have been obliged to prepare and execute their strategic plans. The law intends to provide effective and efficient acquisition and utilization of public resources, accountability and financial transparency.

Academic studies about strategic management/strategic planning in Turkey suc as (Bircan 2002, DPT 2003, DPT 2006, Aktan 2008, Eren 2002, Dinçer, Y1lmaz 2003, Erkan 2008) were conducted in both private and public sectors. Studies were generally performed on private sector before 2003. As a result of adoption of PFMC Law, strategic management concept began to take place in the public sector and also 
academic studies began to focus on this area. In this context, various studies were carried out to evaluate the ongoing strategic planning process in public organizations and to determine the factors affecting the process, employee's perceptions on strategic management/strategic planning and so on. Studies on strategy implementation and strategic assesment may be expected to increase after getting diffused strategic management practices in Turkish public sector. However, at this point, Turkish literature still does not include studies about strategy implementation.

This study presents the findings of a field study of strategy implementation in Turkish public organizations. These findings are discussed in the light of previous literature, so studies about strategy execution/implementation compiled in and strategy implementation process in Turkish public sector was briefly summarized. A questionnaire based on Pedersen's (2008) study was applied to employees of public organizations for determining the employees' perceptions on strategy execution process and strategy execution obstacles. Then comments and suggestions were developed based on findings obtained from the analysis of the data.

\section{STRATEGY IMPLEMENTATION/ EXECUTION DEFINED}

Strategic management is a set of decisions and actions resulting in formulation and implementation of strategies designed to achieve objectives of organization (Pearce, Robinson 2007: 3) and helps the corporations to cope with competitive environment of the 21 st century, provides to achieve above-average gains (Hitt et al., 2007: 6). Poister and Streib (1999: 311) indicated that "strategic management is not a linear process of planning, implementation, and evaluation." Rather, overall purpose of strategic management is to develop a continuing commitment to mission and vision of organization, foster a culture that identifies with and supports mission and vision and maintain a clear focus on organization's strategic agenda throughout all its decision processes and activities. 
Strategic management starts with strategic planning process (Pearce, Robinson 2007: 3; Miller, Dess 1996; Hitt et al., 2007, David 2007). At this process, after the analysis of the external and organizational factors, mission and vision are determined, objectives and strategies are identifed. Strategic management process does not end when organization decides what strategy or strategies to pursue. There must be a translation of strategic thought into strategic action (David, 2007: 262). This translation is easier if managers and employees of organization understand the nature of strategies and become committed to helping organization succeed. Without understanding and commitment, strategy implementation efforts face major problems. Succesfull srategy formulation does not guarantee succesfull strategy implementation. It is always more difficult to do something than to say you are going to do it. Although inextricably linked, strategy implementation is fundementally different from strategy formulation. Characteristics of strategy formulation and implementetion can be contrasted in the following ways (David, 2007: 262):

1) Strategy implementation is managing forces during the action while strategy formulation is positioning forces before the action.

2) Strategy implementation focuses on efficiency while strategy formulation focuses on effectiveness.

3) Strategy implementation is primarily an operational process while strategy formulation is primarily an intellectual process.

4) Strategy implementation requires good intuitive and analytical skills while strategy formulation requires motivation and lesdership skills.

5) Strategy implementation requires coordination amang many persons while strategy formulation requires coordination amang few individuals.

Shah (2005: 293) distinguishes strategy formulation and implementation as in the following quotation: "while strategy formulation is concerned with determining the future direction of the firm by designing appropriate strategies, strategy implementation is translating these into action". The aim of implementaion stage is to complete the transition from strategic planning to strategic management by integrating adopted 
strategies throughout the system (Bryson, 1995). Beside this, developing effective programs, projects, action plans and budgets will bring strategies into life and create a real value for organization and its stakeholders. Hrebiniak (2005: 3) indicated that strategy execution is critical to success and represents a logical set of connected activities that enables an organization to take a strategy and make it work. Hambrick and Cannella (1989: 278) note that converting a new strategy into concrete competitive success is the problem for what managers need a framework. For this reason, the best strategy is the one that is implementable and implemetation should be considered during the formulation process. So the reason for the failure is generally the tendency to treat formulation and implemetation as two separate phases.

Miller and Dess (1996) indicated that strategy implementation is intertwined with organizational change and it is a diffucult process because of naturel tendency to resist change and prefer the status quo, requirement of the involment of many people, the number of variables involved and interconnectedness of elements affecting change.

Sound strategies fail at the hand of the organizations that can't implement it effectively, the first step to solve this problem is to understand how the inherent traits of an organization influence -perhaps even determine- each individual's behavior, and how the collective behavior affects company performance (Neilson et al. 2008: 2).

Consequently, to make the strategies real, factors influencing the success of strategy execution/ implementation process should be identified. So, previous studies about strategy implementation/execution obstacles that are related to field study were briefly introduced in the next section.

\section{STRATEGY IMPLEMENTATION/EXECUTION OBSTACLES}

Since 1960s, numerous studies were made on strategic planning and strategic management. Alexander (1985) claimed that, a large portion of the strategy literature was on the strategy formulation, a very small part of it was on implementation. Noble (1999: 119) also pointed out enough research was not made in this field despite the 
importance of the strategy implementation process. Hrebiniak (2006) mentioned that the management literature produced theories mainly on the planning and strategy formulation, strategy and relevant courses in universities were on strategy formulation and managers who graduate from these schools were also trained on the planning, not on the implementation.

Beer and Eisenstat (2000) determined the silent killers of strategy implementation as top-down or laissez-faire senior management style, unclear strategy and conflicting priorities, an ineffective senior management team, poor vertical communication, poor coordination across functions, business or borders and inadequate down-the-line leadership skills and development.

Noble (1999: 121) notes that one of the success factors of the strategic implemantation is strategic consensus which means "a shared understanding and commitment to a strategic directive between organization members and groups", and higher level of strategic consensus leads to a reduction of uncertainty in the organization and when strategic consensus does not exist, organization members are not operating under the same goals and objectives. Rapert et al. (2002) examined the relationships between communication, consensus and performance factors at their study and they found that widespread existence of vertical communication was required to reach strategic consensus and strategic consensus increased the organizational performance.

Mankins and Steele (2005) surveyed senior executives from 197 companies wordwide to see how succeesful companies were translating their strategies into performance and how effective they were at meeting the financial projection in the strategic plans. The survey indicated that the reasons for the gap between the strategy and performance as "inadequate or unavailable resources, poorly communicated strategy, actions required to execute not clearly defined, unclear accountabilities for execution, organizational silos and culture blocking the execution, inadequate performance monitoring, inadequate consequences or rewards for failure or success, poor senior leadership, uncommitted leadership, unapproved strategy and other obstacles like inadequate skills and capabilities". 
The research carried out by Kaplan and Norton (2005: 3) shows that, 95\% of company's employees are unaware of, or do not understand the strategy. They also find that, "some $60 \%$ of organizations do not link their financial budgets to strategic priorities" and "the compensation packages of $70 \%$ of middle managers and more than $90 \%$ of frontline employees have no link to the success or failure of strategy implementation". According to the authors, if the employees who are closest to customers and operate process that create value are unaware of the strategy, they can't help the effective implementation of the strategy.

Hrebiniak (2005: 17) carried out a joint project with Gartner Group, Inc. at 2003 to gain a clear understanding of challenges faced by managers while making decisions and taking actions to execute the company's strategy and these obstacles have been identified as below:

1. Inability to manage change effectively or to overcome internal resistance to change.

2. Trying to execute a strategy that conflicts with the existing power structure.

3. Poor or inadequate information sharing between individuals or business units responsible for strategy execution.

4. Unclear communication of responsibility and/or accountability for execution decisions or actions.

5. Poor or vague strategy.

6. Lack of feelings of "ownership" of a strategy or execution plans among key employees.

7. Not having guidelines or a model to guide strategy execution efforts.

8. Lack of understanding of the role of organizational structure and design in the execution process.

9. Inability to generate or agreement on critical execution steps or actions.

10. Lack of incentives or inappropriate incentives to support execution objectives.

11. Insufficient financial resources to execute the strategy.

12. Lack of upper-management support of strategy execution.

Hacettepe University Journal of Economics and Administrative Sciences |

Vol 33, Issue 1, 2015

106 
Hrebiniak (2006: 12-14) identified the potential problems that effects the success of strategy execution in contrast with strategy formulation as 1) "managers are trained to plan, not to execute; top-level managers leave strategy implementation to lower-level employees; planning and execution are interdependent; implementation is a process that takes longer than strategy formulation and execution involves more people than strategy formulation."

The survey held by Neilson et al. (2008) had a database of 125,000 profiles over 50 countries representing more than 1,000 companies, government agencies, and notfor-profits and employees at three out of every five companies were not agreed with the statement "important strategic and operational decisions are quickly translated into action". Execution is the result of thousands of decisions made every day by employees acting according to the information they have and their own self-interest. They identified four fundamental building blocks executives can use as "clarifying decision rights, designing information flows, aligning motivators and making changes to structure" to influence those actions.

\section{Pedersen's Strategy Execution Model}

The Strategy Execution Model (SEM) designed by Pedersen (2008), shows how the elements of strategy execution convert the strategy to desired outcomes. In this model, strategy execution process has two key elements: adequate translation of the strategy and adaptation to reality. Elements of the strategy execution at the model are determined as translation, communication, coordination, adaptation, resource allocation and implementation (Figure 1). In the model, strategy implementation process is defined as a more operational phase; strategy execution is defined as a process dealing with the tactics and also includes the implementation. 
Figure 1: Strategy Execution

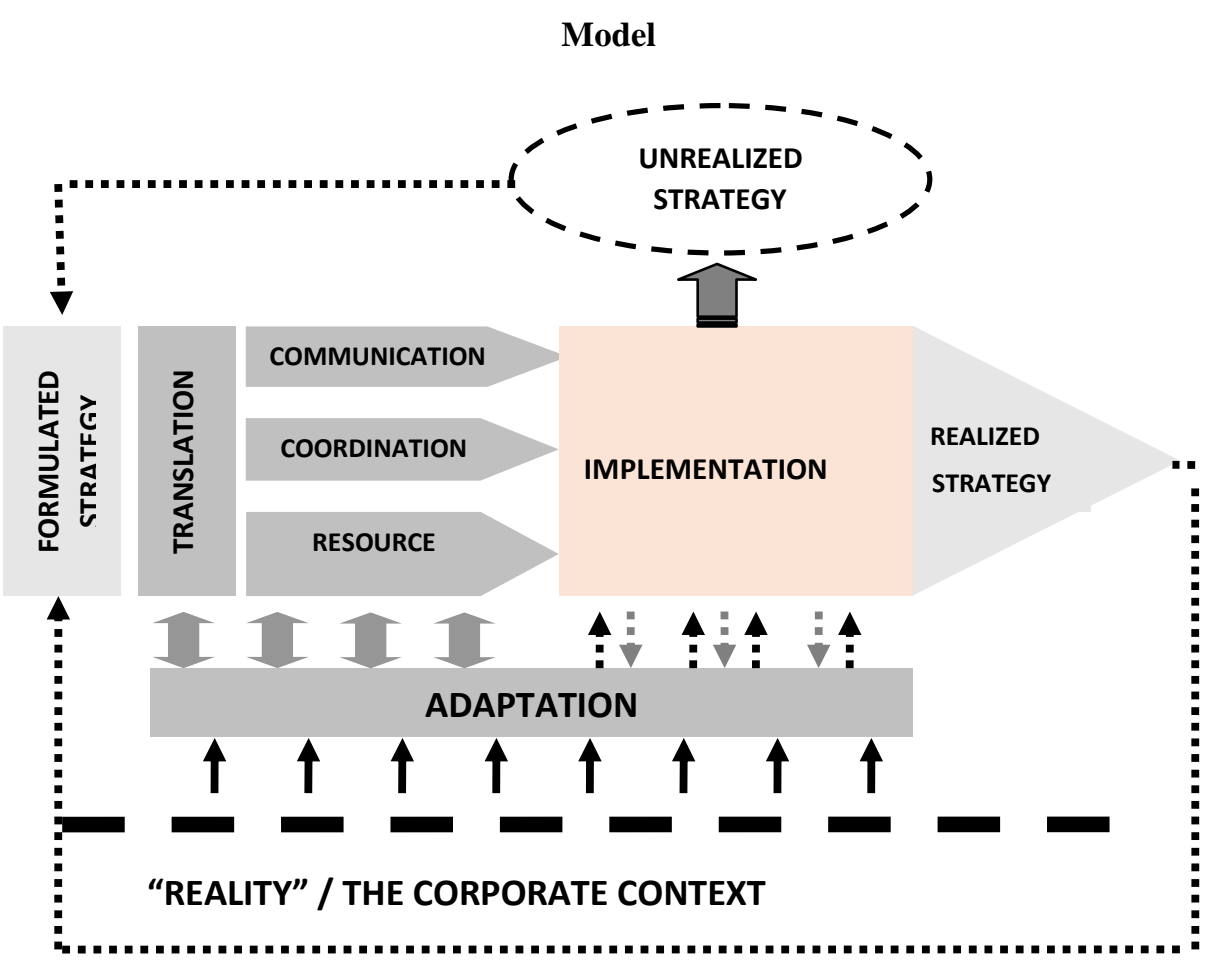

Source: (Pedersen 2008: 66)

The formulated strategy is the outcome of the strategy formulation process and it describes a vision and the long and short range goals of the organization. After formulating the strategy, translation stage starts to translate the strategy into a workable and comprehensible roadmap for the execution of the strategy. At the end of the translation stage, three key outcomes should be provided: "Communication Plan, Coordination Plan and Resource Allocation Plan".

The aim of the communication plan is making all key employees be aware of and understand the strategy and necessity of its execution. The coordination plan should define the method of coordination between the stakeholders and should clarify the structure of information sharing in the strategy execution process. Finally with resource allocation plan, strategy initiatives are linked to the budgets. The resource allocation plan converts every objective and goal of the strategy to "hard cash"- not only money it 
also includes people and technology. When the communication, coordination and resource allocation plans has been developed, the strategy is basically ready to be implemented as everyone knows who is responsible and accountable for the specific actions and which resources will be allocated to execute the strategy.

Adaptation is the process of aligning the strategy with the corporate context or "reality" and constantly making adjustments to the strategy through the execution process. It is an ongoing process that starts with the translation process and ends when the strategy has been implemented and realized. The strategy is converted from thought to action at the implementation phase by implementing communication, coordination and resource allocation plans. At this phase, strategy gets communicated, people are assigned responsibility for the steps and actions and resources are allocated. At the end of the implementation phase, strategy turns to realized or unrealized strategy. Unrealized strategy does not show that the strategy execution went wrong. On the contrary, it shows that the process has been thoroughly adjusted to the corporate context at the adaptation stage. Corporate context involves all factors that can influence the company, its strategy and its strategy execution process like markets, governments, press, competitors, customers, investors, interest groups, trade unions, trends, interest rates and raw material prices.

In this study, data were collected by a questionnaire which is basically generated from the "Strategy Execution Survey" developed by Pedersen (2008) which aims to evaluate the strategy execution performance in an organization and to identify the areas for improvement for successful strategy execution, so strategy execution obstacles used in the survey are briefly explained in this section. These obstacles are resistance, motivation, development hell, groupthink and underperformance.

\subsection{Resistance}

Often, managers responsible for executing a strategy have found that it can be a trying task and failure to execute a strategy is often justified by the claim, that the 
employees are resistant to change. Senior executives all too often assume that people (middle managers and all the rest) are against change (Hamel 1996: 75).That all they really want is to defend the status quo.

At the study designed to determine the strategy execution obstacles held by Hrebiniak (2005: 17) "inability to manage change effectively or to overcome internal resistance to change" was determined as the most important obstacle. Successful strategy implementation needs to gain support for the execution plan and making strategy work often entails employees to perform in certain ways or change their behaviors (Hrebiniak, 2006: 18). At the study of Hrebiniak, “...trying to execute a strategy that conflicts with the existing power structure..." was the second important obstacle of strategy execution. In that case, there won't be the needed support for the execution decisions, actions and activities and there will be a resistance against them. Neilson et al. (2004: 7-8) note that one of the indicators of the resistance is "everyone agrees but nothing changes" and this type of organization is also called "passiveaggressive organization". At these organizations, building consensus to make major changes is very hard and entrenched, underground resistance from field can defeat a corporate group's best efforts. Therefore, strategy execution or implementation generally involves change and managing change is much more than keeping people happy and reducing resistance to new ideas and methods, it also means "knowing the tactics or steps needed to manage the execution process over time" (Hrebiniak, 2005: 17).

Kaplan and Norton (2005) also emphasized that organization should be aligned with the strategy and effective communication of the strategy should be performed within the organization. Implementing strategies and plans successfully depends on investing in communication to make people hear about the intended changes many times and from multiple channels (Bryson, 1995). He indicated that, educational programs, information packets and guidebooks can be used to establish a common language for strategy implementation. Beside the communication, resistance that caused from different attitudes and lack of participation should be avoided. 


\subsection{Motivation:}

No strategy can be effective without motivation and training of employees who have to carry it (Kaplan, Norton 2005: 6). So, the office of strategy management must be sure that human recourses performs activities like carrying out annual performance reviews, personal goal settings, managing employee incentive and competency development programs. The goal should be "making strategy everyone's job". According to Hrebiniak (2005: 17) leadership must be execution biased and it must motivate ownership of and commitment to the execution process. Feedback on performance is also essential for successful strategy implementation and incentives motivate or guide the performance so employees can learn whether desired performance outcomes are being attained (Hrebiniak, 2006: 23). Mankins and Steele (2005: 8) mentioned that companies "should reward and develop execution capabilities of their staffs" and they need to motivate and develop their competencies in order to close the gap between strategy and performance. However, Hrebiniak (2005: 17) pointed out that other important obstacles related with motivation are "lack of feelings of ownership of a strategy or execution plans among key employees" and "lack of incentives or inappropriate incentives to support execution objectives".

\subsection{Development Hell:}

The meaning of the "development hell" is "a period during which a film or other project is trapped in development" and the term is generally used in the media-industry. Projects in development hell are not officially cancelled, but work on them slows or stops. When the concept is adapted to the strategic management, it can be defined as “...can't starting to execute the strategy because of lack of coordination and consensus among key managers and culture of risk aversion or error avoidance" (Pedersen 2008: 51). Other factors that can prevent strategies to pass from planning to implementation phase are "managers are trained to plan, not to execute", "not having guidelines or a model to guide strategy execution efforts", "lack of upper-management support of strategy execution" (Hrebiniak 2006: 12). Mankins and Steele's (2005: 3) study reveals 
that one of the reasons for performance loss is "organizational silos and culture blocking the execution". Hence, organizational culture should be analyzed and cautions should be taken previously for the obstacles related with the culture. At "over managed organizations" which is suffering from "analysis paralysis", managers spend their time checking for others rather than scanning for new opportunities or treats and this type of organizations are frequently bureaucratic and highly political (Neilson et al., 2004: 7-8). Beside these, Pedersen (2008: 51-53) defined the conditions that will block strategy execution and cause development hell as:

$\checkmark$ Employees are unable to move the strategy from planning to execution, because they don't have the skills required to execute the strategy.

$\checkmark$ Rivalry between managers results in a lack of consensus about the strategy.

$\checkmark$ There is a strong culture of risk aversion or error avoidance.

$\checkmark$ The organization is bureaucratic and highly political.

\subsection{Groupthink}

"Groupthink" is the term used to describe a situation where concurrence seeking emerges before a problem or proposed solution has been sufficiently analyzed or evaluated and managers should understand the causes and consequences of concurrence seeking to reduce the human and economic costs of their mistakes (Chapman, 2006: 1392-03). The groupthink model was created by Janis $(1972,1982)$ to explain poor decision making processes and outcomes in groups. He mentioned that groupthink emerged when group members were faced with a decision task in a "provocative situational context" that was involving a moral dilemma or risks of material losses and the decision makers were anxious and fearful of not coping adequately. He determined the groupthink symptoms as "rationalization, mind guarding, censorship, stereotyping, pressure on dissenters, belief in own morality and illusions of unanimity and invulnerability". At the Pedersen's (2008: 51-53) model the situations that will cause groupthink are listed below: 
$\checkmark \quad$ Decision makers are stressed, feel anxious and encourage hasty decision making.

$\checkmark$ Groups shield themselves through mind guarding, rationalization of warnings, direct pressure, self-censorship or illusions of unanimity - from dissenting information that might challenge their assumptions.

$\checkmark \quad$ Groups are characterized by high levels of optimism and a feeling of invulnerability.

$\checkmark$ Groups stereotype outsiders who are opposed to the group consensus as weak, evil, disfigured, ignorant or stupid.

$\checkmark \quad$ The company is developing a disconnection with their customer base.

\subsection{Underperformance}

Culture plays an important role at strategy execution and affects the overall performance. Organizations must develop execution-supportive cultures as execution demands a culture of achievement, discipline, and ownership (Hrebiniak, 2005). In many companies gap between the strategy and performance causes a culture of underperformance and once it has taken root it is very hard to reverse (Mankins, Steele 2005: 3). Managers, expecting failure, spend time covering their tracks rather than working to enhance performance. The organization becomes less-critical and less intellectually honest about its shortcomings and it loses its capacity to perform. Pedersen (2008: 51-53) defined the conditions that will cause underperformance culture as:

$\checkmark$ People avoid committing fully to the strategy, since they expect failure.

$\checkmark$ Employees are "low-balling" when deciding on targets, since they only want targets they know they can reach.

$\checkmark$ The organization has a strong culture of error avoidance. Employees are highly risk-averse and avoid taking responsibility. They emphasize on blaming others.

$\checkmark$ Resistance to change is high.

$\checkmark$ Innovation and creativity is low. 
There are many common points on the researches about successful implementation of strategies. Researches emphasized that strategy and structure, strategy and the human element should be compatible and have developed recommendations on these issues. For the implementation of these recommendations, organizations should define the existing obstacles on the process of implementing the strategy then solutions and strategies should be developed to prevent them.

Strategies will stay on the strategy documents as intends without a successful implementation. Making the strategies real depends on focusing on this goal by heads of public administrations and all employees of the organization. Public employee's thoughts and perceptions should be identified and actions should be taken for changing negative thoughts and perceptions in order to increase the ownership and participation of the employees in the implementation process.

\section{STRATEGY IMPLEMENTATION IN TURKISH PUBLIC} ORGANIZATIONS

It may be useful briefly exploring background of introduction of strategic management concept, which is basicly used in business organizations, into public sector before explicating strategy implementation in Turkish public organizations. The environments of public organizations have changed dramatically in the 1980's due to oil crises, demographic shifts, changing values, taxing limits, privatization, centralization or decentralization of responsibilities, changing values and movements toward information and As employees perceived their organizations highly bureaucratic and think that their work was consistently under control, negative effects of bureaucratic structure to the execution of the strategies should be identified and precautions should be taken. Strategy execution requires excessive communication and coordination among departments, individuals etc. inside the organization as well as actors from external environment of the organization. Organizational structure and culture should foster and support these relations.In Turkey by the adoption of the Public Financial Management and Control Law (PFMCL) at 2003, strategic management concept has 
been started to apply in the public sector. The purpose of the Law is to regulate the structure and functioning of the public financial management, the preparation and implementation of the public budgets, the accounting and reporting of all financial transactions. With the introduction of strategic management concept, government authorities were aimed at strengthening the capacity of policy-making and costing, development of budgeting, ensuring accountability, transparency and the effective, economic and efficient collection and utilization of public resources.

With PFMC Law, public organizations are given the task of preparing their own strategic plans. The strategic plan should comply with development plans, programs, relevant legislation and basic principles of the organization. The strategic plan must include mission and vision, strategic objectives, measurable targets, performance indicators, methods to implement the strategies and the resource allocation plan. The provisions related to the strategic plan came into force on 01.01.2005 and first strategic plans were prepared by the pilot organizations ${ }^{2}$ between 2005-2007. Strategic plans are prepared under the supervision and support of Ministry of Development. A great majority of public organizations prepared their strategic plans between 2008 and 2010 and most of them started these plans to implement between 2009 and 2010. According to the Ministry of Development, 179 central public organizations would start to use strategic planning and performance based budgeting at the time of the field study.

One of the innovations brought about by the Law is performance-based budgeting. Public organizations has been obligated to prepare performance programs annually including actions/activities and resource requirements of them, performance targets and indicators.

The law also ordered the establishment of internal control system in public organizations to achieve the objectives of the organization, to comply with administrative orders, to increase reliability of the information, to promote the effectiveness and efficiency, protection of assets, to ensure compliance with laws and regulations. According to PFMC Law public administrations' financial management 
and control systems consist of spending units, accounting and financial services, ex ante financial control and internal audit. Through the Law, public internal control standards (control environment, risk assessment, control activities, information and communication monitoring standarts) were determined in line with the international standards and they provide the basic management rules which should be taken into consideration in the establishment, monitoring and evaluation of internal control systems.

The connection between the basic policy, objectives and the resources needed to achieve these goals will be established by strategic plans and performance programs and performance results will be shared with the public to provide accountability and transparency by means of annual report. Control process of the strategic management will be carried out successfully by the establishment of internal control system and efficient operation of the system.

\section{FIELD STUDY}

\subsection{Purpose of the Study}

The main objective of the study is to determine perceptions of public employees on strategy execution obstacles in Turkish public organizations. It was researched that whether the employees of public organizations understand the strategic objectives of their organizations, whether strategic objectives are adequately translated to employees, whether the obstacles that may arise in the strategy execution process were perceived in Turkish Public organizations. In this context, the basic question of the study was stated as:

"How were the possible obstacles on the way of the success of strategy execution process perceived by public organizations' employees in Turkey?"

Beside this question sub-research questions designed as follows:

RQ1- Were strategic objectives understood adequately by the employees?

RQ2- Was translation stage perceived as successful?

RQ3- Was resistance obstacle perceived during the strategy execution?

Hacettepe University Journal of Economics and Administrative Sciences |

Vol 33, Issue 1, 2015

116 
RQ4- Was motivation obstacle perceived during the strategy execution?

RQ5- Was development hell obstacle perceived during the strategy execution?

RQ6- Was groupthink obstacle perceived during the strategy execution?

RQ7- Was group underperformance obstacle perceived during the strategy execution?

RQ8- How is the relationship between success of the translation stage and resistance, motivation, development hell, groupthink obstacles?

RQ9- Are the perceptions of the employees differentiate in respect of their demographic characteristics?

\subsection{Methodology and Data}

Data for this research are collected by a questionnaire which was generated from the "Strategy Execution Survey" developed by Pedersen (2008). Once questions in the survey translated into Turkish and question statements were re-adapted for public organizations. During the adaptation, two questions were removed from the survey due to the very similar meaning when translating into Turkish with the question of "There is often a lot of resistance towards new strategic initiatives". These questions were:1. There are many resisters to new strategic initiatives in this organization 2. We have a tendency to ignore new strategic initiatives from top management. One more question, "If I make a mistake I always admit it and assume full responsibility for it", was also removed from the survey, since it was accepted as inappropriate for the purpose of the study. Additionally some personal questions (the name of the public organization and working unit, length of employment, gender, age, education levels) were asked to the participants. The question statements used in the survey were translated back to English and they were given at the tables of the "Findings and Discussions" part of the study. The questionnaire was prepared online by using "surveymonkey.com" and it was organized as Likert scale -1 (strongly disagree), 5 (strongly agree). The question statements were given in a mixed manner and not in the form of Pedersen's grouping. 
As the main purpose of the study is to determine perceptions of public employees on strategy execution obstacles, the question statements in the survey were associated with the research questions. So they were grouped as "Level of Understanding", "Success of Translation Stage", "Resistance Obstacle", "Motivation Obstacle" "Development Hell Obstacle" and "Groupthink Obstacle". The presence of "underperformance obstacle" was assumed to be in the presence of resistance, motivation and development hell obstacles.

There were two questions about level of understanding of the strategic objectives (LU), seven questions about success of translation stage (T), seven questions about resistance obstacle $(\mathrm{R})$, three questions about motivation obstacle $(\mathrm{M})$, nine questions about development hell obstacle (DH) and eight questions about groupthink obstacle (GT) at the questionnaire. New data sets (AvLU, AvT, AvR, AvM, AvDH and AvGT) were created on the basis of arithmetic means of grouped questions.

The data was analyzed by SPSS 16.0, reliability analysis of the data was performed and Cronbach's alpha score were 0.768. Analysis were performed through the average and total average values of the answers given to questions about the research questions and the relationships between the data sets were determined by Pearson and Spearman Correlation Tests. In addition to this, whether the perceptions of the employees differentiate in respect of their demographic characteristics was examined by t-Test, one-way ANOVA for the variables that are suitable for analysis of variance and by Mann-Whitney $\mathrm{U}$ and Kruksal-Wallis $\mathrm{H}$ for the variables that are not suitable for analysis of variance. 0.05 level was accepted as statistically significant at the analysis.

The population of this research consists of the employees of the public organizations that prepared a strategic plan and have started to implement it. Questionnaire was sent to the employees randomly and without number limitation by email. At the end of the survey 171 questionnaires were evaluated from 22 different public organizations $^{3}$ and some characteristics of the participants were listed in Table 1. 
Questionnaires filled by (1) employees that had not involved in the strategic planning activities and (2) employees who were working for less than one year of time at the public organizations were excluded from the data set assuming that they may not have enough knowledge about strategy implementation/execution processes in the organization.

Table 1. Personal Information of Participants

\begin{tabular}{|c|c|c|c|}
\hline & & $\begin{array}{c}\text { Number of } \\
\text { Participants }\end{array}$ & $\begin{array}{c}\text { Ratio of } \\
\text { Participants (\%) }\end{array}$ \\
\hline \multirow{2}{*}{ Organization } & Pilot Organization & 48 & 28 \\
\hline & Other Organization & 123 & 72 \\
\hline \multirow{2}{*}{ Department } & Central Department & 129 & 75,4 \\
\hline & Provincial Department & 42 & 24,6 \\
\hline \multirow{2}{*}{ Gender } & Woman & 62 & 36,3 \\
\hline & Man & 109 & 63,7 \\
\hline \multirow{4}{*}{$\begin{array}{l}\text { Working } \\
\text { Period }\end{array}$} & $1-10$ & 106 & 62 \\
\hline & $11-20$ & 30 & 17,5 \\
\hline & $21-30$ & 33 & 19,3 \\
\hline & $31+$ & 2 & 1,2 \\
\hline \multirow{4}{*}{$\begin{array}{l}\text { Educational } \\
\text { Status }\end{array}$} & Pre-License (High School et all) & 12 & 7 \\
\hline & Undergraduate/License & 120 & 70,2 \\
\hline & Graduate/Masters & 31 & 18,1 \\
\hline & Doctorate & 8 & 4,7 \\
\hline
\end{tabular}

There are two main constrains on this study. One of them is a very short period of time for strategy implementation process in public organizations as majority of the strategic plans were started to implement at 2009 and 2010. It can be said that there was a lack of experience on implementation of strategy in public sector at the year of the study, 2010. Additionally the respondents might have probably answered the survey 
questions based on their previous planning experiences. Another constraint is that the survey was applied on mostly central government institutions and excluded the local institutions, such as municipalities (Bkz. Songür 2008) and province local administrations, which might have different experiences.

\subsection{Findings and Discussions}

In the survey, two questions were asked whether the participants understand strategic objectives of their organizations and whether they are aware of the strategic objectives. Looking at the mean values of these questions at Table 2, it is observed that values are very close to 4 and employees think that they were well aware of and understood the strategic objectives of their organizations.

Table 2. Understanding of the Strategic Objectives

\begin{tabular}{|l|c|c|}
\hline \multicolumn{1}{|c|}{ QUESTION STATEMENTS } & M & SD \\
\hline AU1. I am aware of the strategic objectives. & 3.94 & 0.93 \\
\hline AU2. I understand the strategic objectives. & 3.89 & 0.94 \\
\hline
\end{tabular}

(M: Arithmetic Mean, SD: Standard Deviation)

At the translation stage of the strategy execution, strategy is communicated, coordination for the implementation stage is provided and necessary resources are allocated. Translation stage must be processed effectively to inform employees about the strategy and have their ownership in the strategy.

As arithmetic mean value for translation stage, at Table 3, is 3.43; it can be said that translation stage was perceived as successful in public organizations. This result is supported by higher mean values of the questions about the level of understanding the strategic objectives. According to mean values of the questions, employees think that they were having easy access to information about the strategy and strategy execution; they knew how they contributed to the strategy execution and who was responsible for strategy execution. Mean values of questions about resource allocation (T3 and T7) 
shows that, employees consider that performance program and budget were monitored on a regular basis and resources needed to achieve the strategic objectives were adequately allocated.

Table 3. Success of Translation Stage

\begin{tabular}{|l|c|c|}
\hline \multicolumn{1}{|c|}{ QUESTION STATEMENTS } & M & SD \\
\hline $\begin{array}{l}\text { T1. I have relatively easy access to information about the strategy if I want to } \\
\text { read/study it. }\end{array}$ & 3.66 & 1.10 \\
\hline T2. I know how and/or what to do to achieve the strategic objectives. & 3.51 & 0.98 \\
\hline $\begin{array}{l}\text { T3. The resources needed to achieve the strategic objectives, have been } \\
\text { identified and granted. }\end{array}$ & 3.11 & 1.00 \\
\hline $\begin{array}{l}\text { T4. It is clear to me, who is responsible/accountable for execution decisions } \\
\text { and/or actions. }\end{array}$ & 3.36 & 1.07 \\
\hline $\begin{array}{l}\text { T5. I know how I contribute to the strategy execution. } \\
\text { T6. I have easy access to information that is important for execution } \\
\text { decisions/actions. }\end{array}$ & 3.52 & 0.98 \\
\hline A7. Performance program and budget are monitored on a regular basis & 3.52 & 1.05 \\
\hline \multicolumn{1}{|c|}{ Arithmetic Mean of T } & $\mathbf{3 . 4 3}$ & \\
\hline
\end{tabular}

(M: Arithmetic Mean, SD: Standard Deviation)

In Turkish public administration literature, there is a general acceptance that over centralized and close structure of public sector creates difficulties in delegation of authority to lower level employees for planning and use of resources at the context of strategic management (Söyler, 2007: 112; Yazıc1, 2014: 155). However, by interpreting the scores at Table 3, it could be said that employees of the public organizations perceive the environment appropriate for communication, coordination, adaptation, resource allocation and follow up for strategy implementation. 
Table 4. Resistance Obstacle

\begin{tabular}{|l|c|c|}
\hline \multicolumn{1}{|c|}{ QUESTION STATEMENTS } & M & SD \\
\hline R1. The strategic objectives conflict with the current power structure. & 3.21 & 1.03 \\
\hline $\begin{array}{l}\text { R2. It is relatively easy to generate agreement on critical execution steps or } \\
\text { actions. }\end{array}$ & 3.10 & 0.97 \\
\hline R3. When a new strategy is started to execute I often expect it to fail. & 2.19 & 0.81 \\
\hline R4. There is often a lot of resistance towards execution of new strategies. & 3.32 & 1.07 \\
\hline $\begin{array}{l}\text { R5. When a new strategy is presented, I often think top management has } \\
\text { different intentions. }\end{array}$ & 2.61 & 0.95 \\
\hline $\begin{array}{l}\text { R6. Rumors generally flourish about the strategy. } \\
\text { R7. The phrase: "Everyone knows, but nothing gets done" often captures the } \\
\text { essence of how we work. }\end{array}$ & 3.27 & 1.08 \\
\hline \multicolumn{1}{|c|}{ Arithmetic Mean of R } & $\mathbf{2 . 8 6}$ & 0.83 \\
\hline
\end{tabular}

(M: Arithmetic Mean, SD: Standard Deviation) * Reverse-coded question.

Arithmetic Mean of $\mathrm{R}$, at Table 4, is 2.86; this value shows that employees' perception of resistance obstacle at the strategy execution process was low. In fact "there is often a lot of resistance towards execution of new strategies" statement gets 3.32 mean value but questions reveal the employee's individual resistance (R3, R5 and R6) gets low mean values. Also, employees think that rumors generally did not flourish about the strategy, top management did not have different intentions and it was relatively easy to generate agreement on critical execution steps or actions. Our findings suggest that the most important resistance obstacle is "Everyone knows, but nothing gets done" culture. The second important resistance obstacle is that "strategic objectives conflicted with the current power structure" and this type organizations are classified as passive-aggressive in Neilson et al. (2004: 7-8). At these organizations, building consensus to make major changes is very hard and entrenched, underground resistance from field can defeat a corporate group's best efforts. These scores and current bureaucratic and selfish culture, which aims his/her own social and economic interests rather than the clients' and with the worries of status-quo would change, may be interpreted as two important obstacles for strategic management execution. 
Table 5. Motivation Obstacle

\begin{tabular}{|l|c|c|}
\hline \multicolumn{1}{|c|}{ QUESTION STATEMENTS } & M & SD \\
\hline M1. I have “ownership" in the strategy. & 3.66 & 0.92 \\
\hline $\begin{array}{l}\text { M2. I feel that my opinion is important, when we execute strategy. } \\
\begin{array}{l}\text { M3. Some or all of my rewards and/or incentives are dependent on strategic } \\
\text { objectives. }\end{array}\end{array}$ & 3.49 & 1.12 \\
\hline Arithmetic Mean of M & $\mathbf{3 . 2 6}$ & 1.05 \\
\hline
\end{tabular}

(M: Arithmetic Mean, SD: Standard Deviation)

Arithmetic Mean of M, at Table 5, is 3.26; this value shows that employees feel highly motivated in execution process and they don't perceive motivation obstacle. Looking at the average values of the questions, high level of ownership in strategy is seen and employees believe that their opinions were important when executing the strategy. Beside these positive results, question M3 gets a lower mean value. For successful execution of strategies, having motivated employees is very important. High motivation leads to high ownership in strategy. For this reason, employees should be motivated through rewards and incentives and participated in the execution process. So, in order to increase the motivation level, public organizations should develop reward and incentive systems compatible with the strategic objectives.

Development hell occurs when the strategy can't pass to the implementation stage because of lack of coordination and consensus between key managers, risk and error avoidance. Arithmetic mean of $\mathrm{DH}$, at Table 6, is 3.05; this value indicates that there is a perception of development hell obstacle in public organizations but the level of the perception is not so high. According to the mean values of the questions, employees perceive their organizations highly bureaucratic and think that their work was consistently under control. Also, the questions about risk and error avoidance have high mean values. These finding indicate that employees perceive a highly risky and error avoidance working environment in their organizations. Beside these, employees can openly and honestly express their concern about the strategy and/or the execution 
process and they think that, it was acceptable to change/revise strategic targets during the execution process. But one of the most important indicators of development hell obstacle "being slow of the process of execution of new strategies in the organization" was perceived by the employees. When all values are examined together, it can be said that the structure of public organizations was supporting the development hell obstacle.

Table 6. Development Hell Obstacle

\begin{tabular}{|l|c|c|}
\hline \multicolumn{1}{|c|}{ QUESTION STATEMENTS } & A & SD \\
\hline $\begin{array}{l}\text { DH1. I can openly and honestly express my concern about the strategy and/or } \\
\text { the execution process. }\end{array}$ & 2.33 & 1.03 \\
\hline $\begin{array}{l}\text { DH2. It is acceptable to change/revise strategic targets during the execution } \\
\text { process. }\end{array}$ & 2.25 & 0.88 \\
\hline $\begin{array}{l}\text { DH3. The organization accepts error rather than punishes people for making } \\
\text { them.* }\end{array}$ & 3.35 & 1.04 \\
\hline $\begin{array}{l}\text { DH4. The organization is positive about taking risks.* } \\
\text { DH5. When deciding organizational targets, targets that are certainly } \\
\text { achievable are chosen. }\end{array}$ & 3.28 & 0.98 \\
\hline DH6. The organization is highly bureaucratic. & 3.36 & 1.09 \\
\hline DH7. I think that my work is consistently under control & 3.13 & 1.08 \\
\hline $\begin{array}{l}\text { DH8. Competition between managers affects the strategy execution process } \\
\text { negatively. }\end{array}$ & 3.08 & 1.19 \\
\hline DH9. Execution process of new strategies is fast in the organization.* & 3.23 & 0.99 \\
\hline Arithmetic Mean of DH & $\mathbf{3 . 0 5}$ & \\
\hline
\end{tabular}

(M: Arithmetic Mean, SD: Standard Deviation) * Reverse-coded questions.

These findings may be supported by various other factors. a) public sector products are mostly in service form with high volume and difficult to measure its quality and performance. Because of the social aspects of these product, it is also inappropriate for a cost/benefit analysis. b) Another factor is not having enough capacity for human resources management, total quality management, and performance 
management to contribute the strategy execution process. c) customary way of doing things in the public sector demanding more public resources without sharing any responsibility for both service providers and clients. This system is highly bureaucratic and avoids risk and error as possible.

Groupthink obstacle affects the decision-making process in strategy execution. Employees who are excessively dependent on the group norms, ignoring the ideas outside the group decisions and thinking of the organization as having no problems leads to groupthink obstacle and leads to wrong decision making for important issues. Arithmetic mean of GT, at Table 7, is 2.97; this value indicates the level of perception of groupthink obstacle was low. Mean values of the questions reveal that employees feel reluctant to explain their opinions, ideas or information that conflicts with the generally accepted tendencies and opinions/ideas that conflicts with the generally accepted tendencies are not ignored or refused. Questions that measure the perception of optimism (GT4 and GT5) get lower values so high levels of optimism that will lead the groupthink is not perceived in public organizations.

Overload stress and anxiety prevents the evaluation of alternatives and leads to wrong decisions. The values of GT6 and GT8 show that, employees often think that decisions are made hastily and without careful consideration of alternatives and they generally feel stressed due to time restraints, demands or other pressures. Beside these, they think that execution decisions were made only after careful consideration of alternatives. So they think generally decisions were made hastily but decisions about execution were made more carefully and with good consideration of the alternatives. They also think that there is intermediate top management support in the execution process. 
Table 7. Groupthink Obstacle

\begin{tabular}{|l|c|c|}
\hline \multicolumn{1}{|c|}{ QUESTION STATEMENTS } & M & SD \\
\hline $\begin{array}{l}\text { GT1. Execution decisions are made only after careful consideration of } \\
\text { alternatives. }\end{array}$ & 2.87 & 1.01 \\
\hline $\begin{array}{l}\text { GT2. I feel reluctant to explain my opinions, ideas or information that } \\
\text { conflicts with the generally accepted tendencies. }\end{array}$ & 2.68 & 1.05 \\
\hline $\begin{array}{l}\text { GT3. If I explains opinions or ideas that conflicts with the generally accepted } \\
\text { tendencies, it is ignored or refused. }\end{array}$ & 2.94 & 1.00 \\
\hline $\begin{array}{l}\text { GT4. When something bad happens, it is mostly due to external factors, over } \\
\text { which we have no real control. }\end{array}$ & 2.91 & 0.97 \\
\hline $\begin{array}{l}\text { GT5. I don't think there is anything that can truly threaten the organization. } \\
\text { Arithmetic Mean of GT } \\
\text { consideration of alternatives. }\end{array}$ & 2.81 & 1.02 \\
\hline $\begin{array}{l}\text { GT7. Top management encourages and welcomes critical ideas and questions } \\
\text { about the strategy or the execution process.* }\end{array}$ & 2.97 & 0.97 \\
\hline $\begin{array}{l}\text { GT8. I generally feel stressed due to time restraints, demands or other } \\
\text { pressures. }\end{array}$ & 3.40 & 1.05 \\
\hline
\end{tabular}

(M: Arithmetic Mean, SD: Standard Deviation) $*$ Reverse-coded questions.

Top managers in Turkish public sector such as undersecretary, general director, department head etc. are approximately sitting in their office for 2-3 years. They should have time for setting strategic objectives, realizing and evaluating them. .

The formation of underperformance expectations in organizations depends on many factors. Among these "low ownership in the strategy because of low motivation, high error and risk avoidance and high resistance to change" are the most important factors. At this study underperformance obstacle was not associated with the research questions and it is accepted that in the presence of resistance, motivation and development hell obstacles underperformance obstacles would occur. At the survey, level of resistance perception is low, level of motivation perception is high and overall 
the mean value of development hell obstacle is 3.05. In addition to these, "when a new strategy is started to execute I often expect it to fail (R3)" statement gets 2.19 mean value. According to these results, employees of the public organizations don't perceive underperformance obstacle at their organizations.

At the study, the relationships between the successes of the translation stage, the motivation level, resistance, development hell and groupthink obstacles and the relationships between these obstacles was analyzed with Pearson and Spearman Correlation Tests (Table 8 and Table 9).

Table 8. Correlations Between Variables (Pearson Correlation-2-tailed)

\begin{tabular}{|l|l|c|c|c|c|}
\hline & & AvT & AvR & AvDH & AvGT \\
\hline \multirow{2}{*}{ AvT } & Pearson Correlation & 1 & & & \\
\cline { 2 - 6 } & Sig. (2-tailed) & & & & \\
\hline \multirow{2}{*}{ AvR } & Pearson Correlation & $-.451^{* *}$ & 1 & & \\
\cline { 2 - 6 } & Sig. (2-tailed) & .000 & & & \\
\hline \multirow{3}{*}{ AvDH } & Pearson Correlation & $-.180^{*}$ & $.445^{* *}$ & 1 & \\
\cline { 2 - 7 } & Sig. (2-tailed) & .019 & .000 & & \\
\hline \multirow{2}{*}{ AvGT } & Pearson Correlation & $-.414^{* *}$ & $.517^{* *}$ & $.307^{* *}$ & 1 \\
\cline { 2 - 7 } & Sig. (2-tailed) & .000 & .000 & .000 & \\
\hline
\end{tabular}

*. Correlation is significant at the 0.05 level (2-tailed).

**. Correlation is significant at the 0.01 level (2-tailed).

According to the correlation values at Table 8, all the correlation levels are significant and there are intermediate level negative relationship between success of translation stage and resistance obstacle, low level negative relationship between success of translation stage and development hell obstacle and intermediate level negative relationship between success of translation stage and groupthink obstacle. As the success of the translation stage increases the level of perception of resistance, development hell and groupthink obstacles decreases. 
There is a more strong relationship between success of translation stage and resistance/groupthink obstacles then development hell obstacle. Correlations within the resistance, development hell and groupthink obstacles are between the 0.30 and 0.70 values. According to these results, there is intermediate level positive relationship between resistance, development hell and groupthink obstacles.

Relationships between the perceived motivation level and the resistance, development hell and groupthink obstacles were analyzed by Spearman Correlation Test (Table 9).

Table 9. Correlations Between Variables (Spearman Correlation-2-tailed)

\begin{tabular}{|l|lcccc|}
\hline \multirow{2}{*}{ AvM } & & AvT & AvR & AvDH & AvGT \\
\cline { 2 - 6 } & Correlation Coefficient & $.555^{* *}$ & $-.304^{* *}$ & $-.238^{* *}$ & $-.366^{* *}$ \\
\cline { 2 - 6 } & Sig. (2-tailed) & .000 & .000 & .002 & .000 \\
\hline
\end{tabular}

**. Correlation is significant at the 0.01 level (2-tailed).

All the correlation levels are significant and there is intermediate level positive relationship between the perceived level of motivation and the success of translation stage. While executing the strategy, if translation of the strategy is successful, employees will have ownership in the strategy and they will be more motivated to execute the strategy. According to the correlation values between motivation level and the resistance/groupthink obstacles, there is an intermediate negative relationship between them. And, there is a low level negative relationship between the motivation level and the development hell obstacle. So, obstacles will be less if motivation level of the employees is high. 
Table 10. Kruksal Wallis Test for Perception of Employees on

Motivation Level

Test Statistics ${ }^{\mathrm{a}, \mathrm{b}}$

\begin{tabular}{|l|c|}
\hline & OrtM \\
\hline Chi-Square & 9,593 \\
\hline df & 3 \\
\hline Asymp. Sig. &, 022 \\
\hline
\end{tabular}

a. Kruksal Wallis Test, b. Grouping Variable: Education

At the study it was also analyzed that whether the perceptions of the employees differentiate in respect of their personal differences like working in a pilot organization or not, working in a central department or provincial department, working years and education level. Analysis results show that employees' perception on the motivation level differentiates according to the education level (Table 10). Out of this, there is no difference between the employee perceptions on the success of translation stage, motivation level, resistance, development hell and groupthink obstacles by personal characteristics.

\section{CONCLUSIONS AND RECOMMENDATIONS}

The aim of the study is to determine perception of strategy execution obstacles in Turkish public organizations. By the analysis, the main problems perceived during the strategy execution were determined as "bureaucratic structure, culture of risk and error avoidance, structure that supports resistance to strategies, no reward and incentive systems compatible with the strategic objectives and intermediate level of top management support". The survey results evaluated as a whole and the following recommendations developed for successful strategy execution in Turkish public organizations:

Resistance obstacle is not so high considering the overall score which is 2.86 . However, the power structure and strategic objectives are not compatible with each 
other and resistance on the new strategy execution has high scores with 3.21 and 3.32 respectively. In order to solve this problem, a comprehensive performance program should be prepared and organizational objectives should be translated into individual level objectives. Performance program should include how the strategy will be communicated, how the responsibility and resource allocation will be done. So, nobody in the organization should be suspicious about these issues. Performance objectives of the department should be translated to the sub-departments, divisions and finally to the individual objectives. So, all the employees should be informed well about his/her responsibilities in strategy execution process. Departments responsible for the performance objectives should prepare annual action plans, and realized activities should be reported periodically and for unrealized activities, reasons for not realizing them should be studied and solutions should be developed for them.

Survey results indicate that employees perceived as their rewards and incentives are not related and dependent on strategic objectives with the score of 2.65 . In order to increase the motivation of employees in the public organizations a reward and incentive systems compatible with the strategic objectives should be developed. This system should be fair in considering internal, external and individual contribution. Internal fairness is about "equal jobs should get equal payment" and external fairness is about market conditions for a specific job. If the public organizations pay far below the average market prices, this would not be fair. The system should also consider individual performance differences. Developing a reward and incentive system compatible with the strategies of the organization would motivate the employees to reach individual and departmental objectives. As a result, organizational performance would increase and it would likely lead to achieve strategic objectives.

As employees perceived their organizations are highly bureaucratic and think that their work was consistently under control, negative effects of bureaucratic structure to the execution of the strategies should be identified and precautions should be taken. Strategy execution requires excessive communication and coordination among departments, individuals etc. inside the organization as well as 
actors from external environment of the organization. Organizational structure and culture should foster and support these relations.

As public employees perceived intermediate top management support in the execution process, top managements' support to strategic management should be increased: For a successful strategy execution, top managements' ownership in strategy execution should be increased, Increase in employees' perception of support will lead to high motivation and high ownership in strategic objectives. However, this is not an easy issue for the public sector unless upper level public managers stay in their office for a period of time that allows them for execution and evaluation of the strategy.

Horizontal Communication and coordination between managers and departments should be enhanced: As the strategies are executed by all employees, managers and departments together, communication and coordination between these groups should be well established and participation should be increased in strategy implementation process and also teamwork should be encouraged.

Errors should be accepted as a learning tool and culture of risk aversion should be avoided in order to change employees' perception of highly risk and error avoidance working environment in their organizations. Unless employees are not satisfied, it would not be possible to satisfy the clients of the public service. Managers and employees focus on errors rather than results and culture of high risk aversion leads to development hell obstacle. Excessive controls to detect errors are increasing mistrust between managers and employees in the public organizations.

As a result, the successful management of the strategy execution process depends on focusing on this goal by all the employees, primarily the upper managers. All activities concerning the implementation process of the strategy should be embraced by all employees and managers. Beside these, sharing examples of successful applications among public organizations would prevent similar errors in the process of strategy implementation 


\section{NOTLAR}

${ }^{1}$ http://en.wikipedia.org/wiki/Development_hell

${ }^{2}$ Ministry of Agriculture and Rural Affairs, General Directorate of Bank of Provinces, Kayseri Metropolitan Municipality, Hacettepe University, Turkish Statistical Institute, General Directorate of Highways, General Directorate of Health for Border and Coastal Areas, Denizli Province Local Administration

${ }^{3}$ Ministry of Agriculture and Rural Affairs, General Directorate of Bank of Provinces, Kayseri Metropolitan Municipality, Turkish Statistical Institute, General Directorate of Highways, General Directorate of Family and Social Researches, Hacettepe University, General Directorate of Health for Border and Coastal Areas, National Productivity Centre, Turkish Patent Institute, Prime Ministry Higher Auditing Board, The Scientific and Research Council of Turkey, Turkish Industry Management Institute, Small and Medium Enterprises Development Organization, Ministry of Finance, Ministry of Transport, Labor and Social Security, General Directorate of Security, Undersecretariat of State Planning Organization, Undersecretariat of Treasury, Undersecrateriat of Foreign Trade

\section{REFERENCES}

Aaltonen, P., H. Ikävalko (2002) "Implementing Strategies Successfully", Integrated Manufacturing Systems, 13(6), 415- 18.

Aktan, C. (2008) "Stratejik Yönetim ve Stratejik Planlama", ÇEIS- Çimento Endüstrisi İşverenleri Sendikası Yayını, 4(22), 4-21.

Alexander, L. (1985) "Successfully Implementing Strategic Decisions", Long Range Planning, 18(3), 91-7.

Beer, M., R.A. Eisenstat (2000) '"he Silent Killers of Strategy Implementation and Learning", Sloan Management Review, 29-40.

Bircan, İ. (2002) "Kamu Kesiminde Stratejik Yönetim ve Vizyon", Planlama Dergisi, Özel Say1DPT'nin Kuruluşunun 42. yıl1, 11-20.

Bryson, J.M. (1995) Strategic Planning for Public and Non-profit Organizations, San Francisco: Jossey-Bass. 
Chapman, J. (2006) "Anxiety and Defective Decision Making: an Elaboration of the Groupthink Modei", Management Decision, 44(10), 1391-404.

David, F. R. (2007) Strategic Management: Concepts and Cases, NY: Prentice Hall.

Dinçer, Ö., C. Yılmaz (2003) Kamu Yönetiminde Yeniden Yapılanma: -1- Değişimin Yönetimi İçin Yönetimde Değişim, Ankara: Başbakanlık.

DPT (2003) Kamu Kuruluşları İçin Stratejik Planlama Kılavuzu, Ankara: DPT Yayınları.

DPT (2006) Kamu Kuruluşları için Stratejik Planlama Kılavuzu, (2. Sürüm), online at http://www.sp.gov.tr/documents/SP-Kilavuz2.pdf].

Eren, E. 2002 Stratejik Yönetim ve İşletme Politikası, İstanbul: Beta.

Erkan, V. (2008) Kamu Kuruluşlarında Stratejik Planlama: Türkiye Uygulaması ve Kuruluşlarda Başarıyı Etkileyen Faktörler, Ankara: Türkiye İstatistik Kurumu Matbaas1.

Hambrick, D.C., A.A. Cannella Jr. (1989) "Strategy Implementation as Substance and Selling", The Academy of Management Executive, III:4, 278-85.

Hamel, G. (1996) "Strategy as Revolution", Harvard Business Review, July-August, 69-82.

Hitt, M.A., R. E. Hoskisson, D.R. Ireland (2007) Management of Strategy, OH: Thomson-South Western.

Hrebiniak, L.G. (2005) Making Strategy Work, Wharton School Publishing.

Hrebiniak, L.G. (2006) 'Obstacles to Effective Strategy Implementation', Organizational Dynamics, 35(1), 12-31.

Janis, I. L. (1972) Victims of Groupthink: A Psychological Study of Foreign-Policy Decisions and Fiascoes, Oxford: Houghton Mifflin.

Janis, I.L. 1982 Groupthink,. Boston: Houghton Mifflin.

Kaplan, R.S., D.P. Norton (2005) "The Office of Strategy Management", Harvard Business Review, 1-11.

Mankins, M.C., Steele, R. (2005) "Turning Great Strategy into Great Performance", Harvard Business Review, 1-10. 
Miller, A, G.D. Dess (1996) Strategic Management, McGraw-Hill.

Neilson, G., B.A. Pasternack, D. Mendes (2004) "The Seven Types of Organizational DNA", Strategy + Business, $2-10$.

Neilson, G.L., K.L. Martin, E. Powers (2008) "The Secrets to Successful Strategy Execution", Harvard Business Review, 61-70.

Noble, C. H. (1999) "The Eclectic Roots of Strategy Implementation Research", Journal of Business Research, 45, 119-34.

Pearce, J.A., R.B. Robinson (2007) Strategic Management-Formulation, Implementation and Control,. New York: McGraw-Hill Irwin.

Pedersen, K.L. (2008) "Cracking the Code of Strategy Execution", unpublished Master Thesis, Copenhagen Business School.

Poister, T.H., G. Streib (1999) "Strategic Management in the Public Sector: Concepts, Models and Processes", Public Productivity \& Management Review, 22(3), 308-25.

Rapert, M.I., A. Velliquette, J.A. Garretson (2002) 'The Strategic Implementation Process Evokig Strategic Consensus Through Communication', Journal of Business Reseach, 55, 30110.

Shah, A.M. (2005) "The Foundations of Successful Strategy Implementation", Global Business Review, 6(2), 293-302.

Songür, N. (2008) "Stratejik Plan Hazirlamakla Yükümlü Belediyelerin Deneyimleri Üzerine Bir Araştırma" in L. Özcan, F. Yurttaş, Ö. Köseoğlu, S. Gülener (eds.) 1. Ulusal Yerel Yönetimler Sempozyumu, 71-84, Adapazarı: Sakarya Üniversitesi İktisadi ve İdari Bilimler Fakültesi.

Söyler, İ. (2007) "Kamu Sektöründe Stratejik Yönetim Uygulanabilir mi? Engeller/Güçlükler", Maliye Dergisi, 152, Ocak- Haziran, 103-15.

Yazıcı, K. (2014) "Kamuda Stratejik Planlamanın Başarısız Olma Nedenleri ve Çözüm Önerileri", SÜ İïBF Sosyal ve Ekonomik Araştırmalar Dergisi, 134-71. 